\title{
THE POTENTIAL OF NON-WOOD PULP IN EUROPEAN CIRCULAR BIOECONOMY
}

\author{
Peter ŠEDÍK; Filip TKÁČ; Danka MORAVČíKOVÁ
}

${ }^{1}$ Institute of Marketing, Trade and Social Studies, Faculty of Economics and Management, Slovak University of Agriculture in Nitra, Nitra, Slovakia

\begin{abstract}
European Union is striving towards sustainability and circularity due to many serious reasons such as limited natural resources, climate change, degradation of ecosystems, biodiversity and lands etc. To address these challenges, the EU created in 2012 so called "European Bioeconomy Strategy" which aims towards innovative and sustainable use of renewable resources including the concept of circular bioeconomy and bio-based economy. Biomass and Bio-based products have great potential for production and recycling the raw materials including agricultural residues. The significant potential is in lignocellulose retrieved from agriculture and forestry residues involving waste, straws or other by-products.
\end{abstract}

Purpose: The aim of this research is to study and describe the potential of pulp from fibres other than wood in Europe.

Design/methodology/approach: The research is based on secondary data obtained from Faostat and various research studies. Data were analysed by using descriptive statistics.

Findings: Results showed that the world production of pulp from fibres other than wood has decreasing trends. In total only 11,8 mil. tonnes were produced worldwide in 2019. Approximately $82 \%$ of overall non-wood pulp is produced in Asia, where the largest producer is China. The similar trend can be observed in European union as well. The major producers are Czech Republic, Spain, Italy, France, Poland and Hungary. Slovakia produced in 2019 only 1000 tonnes. Pulp from fibres other than wood offers a huge potential for papermaking industry in countries that have no or limited access to wood fibres. Non-wood fibres can be produced from cereal straws, grasses and from other agricultural residues. Furthermore, the production of non-wood pulp provides opportunities for food sectors as it can used as raw material for degradable food packaging which will contribute to sustainable consumption. In addition, supporting the processing agricultural residues will indirectly foster bioeconomy in the rural areas.

Research limitations: The primary limitation to the generalization of these results is the character of this paper which includes only pilot study, therefore a further in-depth research should be addressed.

Keywords: circular bioeconomy, biomass, pulp, agricultural residues

\section{Introduction}

According to European bioeconomy strategy, there exist five objective: ensuring food and nutrition security, managing natural resources sustainably, reducing dependence on non-renewable resources, mitigating and adapting to climate change and strengthening European competitiveness and creating jobs. Moreover, it contains 14 concrete actions including the deploying bioeconomies at local level across the whole of Europe by creating agenda for sustainable farming and food

https://doi.org/10.11118/978-80-7509-820-7-0370

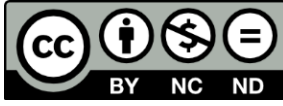


systems, biobased products and forestry (European Commission, 2019). Bioeconomy offers great opportunities for paper and pulp sector in the European Union including new concept for business with wood and non-wood fibres, novel materials, bio-based products, chemicals or fuels (European Commission, 2021).

\section{Literature review / Research Background}

Paper and pulp industries play an important role in bio-energy production in many European countries. Currently, these industries use wood and recovered (recycled) paper as the main source of pulp (Gavrilescu et al., 2008). There are a number of non-wood raw materials on the market for the production of paper pulp as well as a number of chemical processes for its production (Leponiemi, 2008). According to Fernández-Rodríguez et al. (2017) there are three categories of non-wood fibres used in pulp production. The availability of these non-wood raw materials represents an opportunity to reduce wood consumption in the paper industry. Alternative sources of pulp for paper production include raw materials from special-purpose crops (jute, hemp, flax), agricultural residues (cereal straw, rice straw, corn and rapeseed stalks) or naturally uncultivated plants such as various grasses and cane (Kamoga et al., 2016 ; Gomez - Sanchez et al., 2017).

According to Liu et al., (2018) non-wood fibres can be produced from cereal straws, grasses and from other agricultural residues:

- Gramineous fibre materials

bamboo, bagasse, rice straw, wheat straw, sorghum residue, corn straw, reed,

- Bast fibre materials mulberry, tan skin, cotton stalk bark, kenaf, jute, hemp, flax

- Seed hull fibre materials cotton and cotton linters

- Leaf fibre materials banana leaves, sisal, abaca, sugarcane leaves

Non-wood plant raw materials that have been tested so far for pulp production include the following crops: cereal straw, rice straw, sugar cane bagasse, bamboo, cane, esparto, kenaf, corn stalks, sorghum stalks, rape, sunflower. In general, these raw materials are used to produce shorter fibres as a substitute for hardwood pulp. Non-wood plant resources such as cotton, flax, hemp are used to make longer fibers that are substitutes for softwood pulp (Hurter, 2001). Fibres of Jute plant are characterised by high content of cellulose (Abd El-Sayed et al. 2020). The production of paper from non-wood fibres has a lower impact on the environment. Firstly, it is the use of agricultural residues itself, thus preventing their combustion, which pollutes the air. Secondly, the process of pulping the non-wood materials itself generates satisfactory results using sulphur-free methods. Furthermore, the processing requires less energy for most non-wood fibres, which can lead to energy savings (Stoica et al., 2010). The use of non-wood fibres resources for pulp production has several economic and environmental aspects, such as faster growth compared to wood, continuous cultivation in the case of wild plants or availability 
in larger quantities at agricultural residues of some major crops (Huang et al., 2008; Hedjazi et al., 2009; Sanchez et al., 2010). In addition, it is expected that the demand for pulp from non-woody biomass will increase in the industrialized countries of Europe and North America. The main reason is environmental aspects such as the depletion of forest resources and the ecologically burdensome disposal of agricultural residues (Bajpai, 2018).

\section{Methodology}

The paper is based on desk research focused on various studies and reviews oriented on pulp produced from fibres other than wood and non-wood pulp.

Secondary data were obtained from Faostat in order to analyze the current situation in the market with pulp from fibres other that wood. The analysis was conducted by applying descriptive statistics.

\section{Results and discussion}

According to Figure 1, the world production of pulp from fibres other than wood had increasing tendency from 2001 till 2007. Since than it has been decreasing. In 2019 the total production reached 11,8 million tonnes. The majority of pulp from non-wood fibres was produced in Asia $(82.8 \%)$, followed by Europe $(9.2 \%)$ and America (6.5\%). The main producer in 2019 was China generating approximately 5,88 million tonnes followed by India with 3 million tonnes (Figure 2).

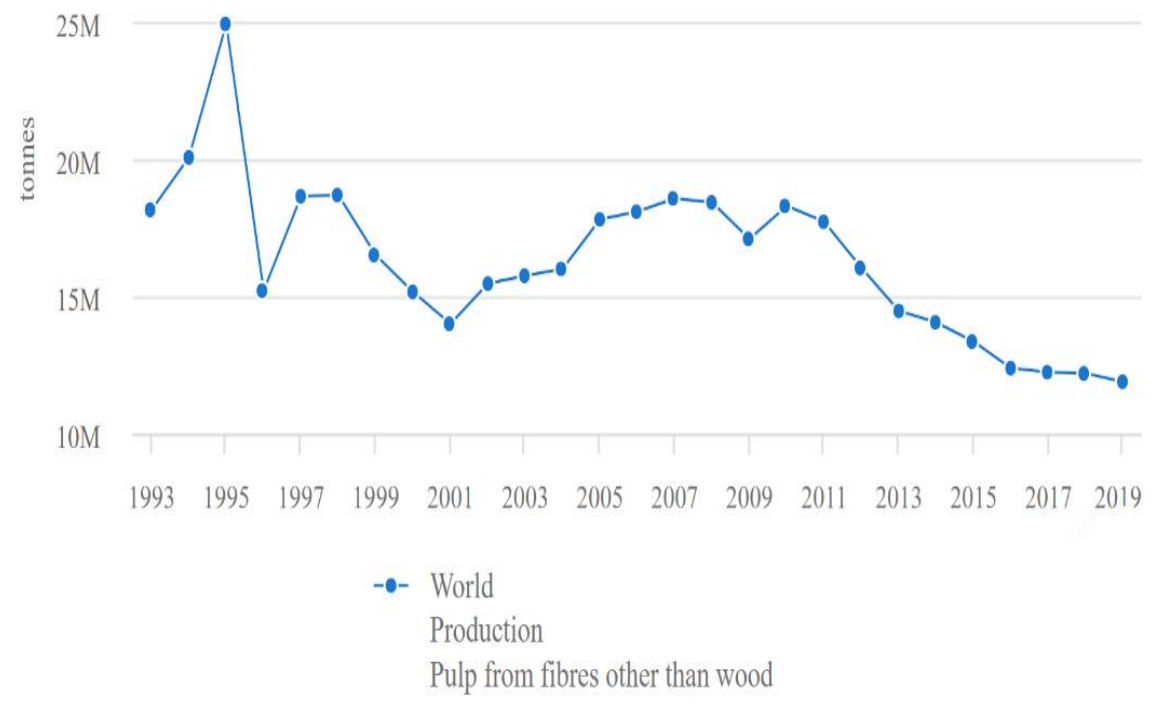

Figure 1.World production of pulp from fibres other than woods for years 1993 2019

Source: Faostat, 2021 


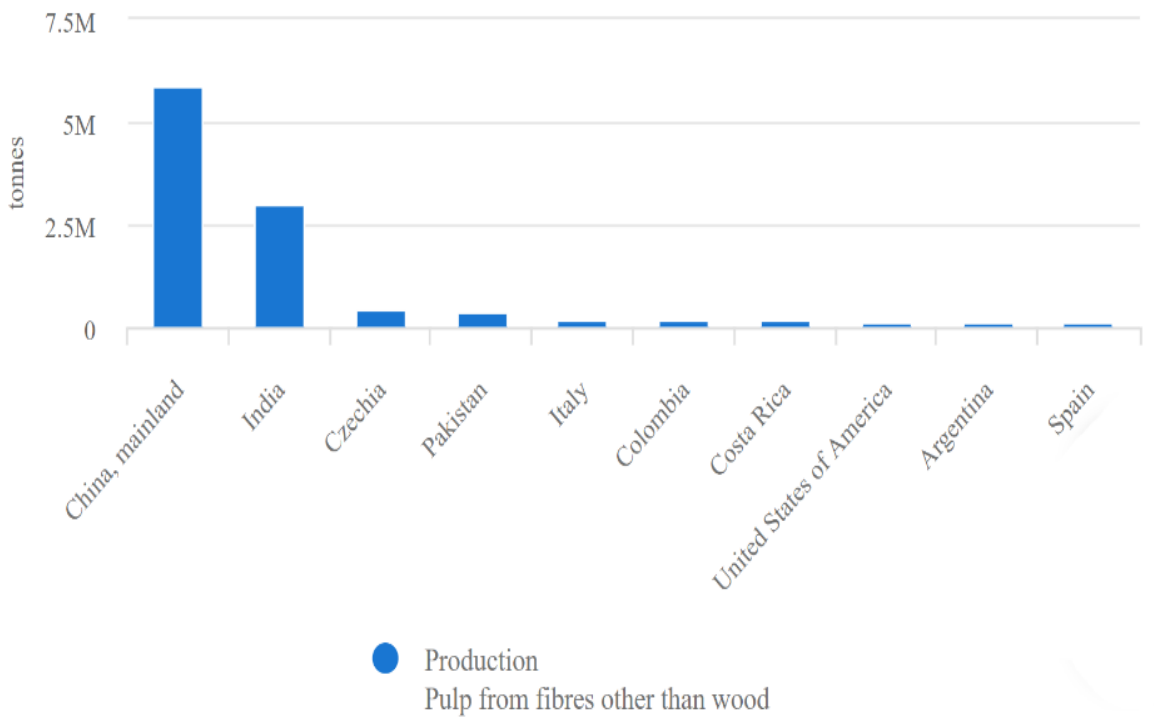

Figure 2. Top 10 countries in production of pulp from fibres other than wood in 2019

Source: Faostat, 2021

The pulp from fibres other than wood was produced in 2019 only by few member states of European union. Table 1 shows that the major producer was Czech Republic with 441278 tonnes followed by Italy, Spain, France, Poland, Hungary, United Kingdom of Great Britain and Northern Ireland, Belgium and Slovakia. European union produced in 2019 around 996200 tonnes.

Table 1. Production of pulp from fibres other than wood in 2019 within EU

Czech Republic

Italy

Spain

France

Germany

Poland

Hungary

United Kingdom of Great Britain and Northern Ireland

Belgium

Slovakia
$441278 \mathrm{t}$

$202890 \mathrm{t}$

$122000 \mathrm{t}$

$81000 \mathrm{t}$

$73242 \mathrm{t}$

$51000 \mathrm{t}$

$15000 \mathrm{t}$

$7000 \mathrm{t}$

$1790 \mathrm{t}$

$1000 \mathrm{t}$

Source: Faostat, 2021

The production of pulp from fibres other than wood have many advantages such as worldwide surplus of non-wood materials including agricultural residues, shorter cycle growth of these fibres, huge potential in paper industry as these fibres have 
special papermaking properties (low content of lignin), pulping process is shorten. Pulp from fibres other than wood may reduce the deforestation process as it represents an alternative for both softwood and hardwood fibres. In addition, if it is used with wood fibres and recycled pulp, the wood resources can be stretched (Abd El-Sayed et al. 2020, Singh et al. 2010). The huge potential is seen in using these fibres and pulp for biocomposites in textile or automotive industry (Mutia \& Risdianto, 2017). Moreover, pulp made of fibres other than wood may be use in food industry as a biodegradable products or biodegradable food packaging as a substitute to plastic (Sharma, 2021).

Despite great potential of non-wood fibres, there exist several problems related to seasonal availability of raw materials at local level, high transportation and storage costs, small-scale mills, low chemical recovery system and environmental drawbacks due to e loss of pulping chemicals (Abd El-Sayed et al. 2020; Gominho et al. 2018; Naqvi et al. 2018).

\section{Conclusion}

Pulp from fibres other than wood is produced mainly in China and India. The main producer in European Union is Czech Republic and Italy. Currently, the world production has decreasing tendency. Desk research showed a great potential of pulp from non-wood fibres in bioeconomy especially in paper industry as well as in food industry as a suitable material used in production of biodegradable food products and packaging. The paper represents a pilot study, therefore further in-depth research should be conducted.

\section{References}

1. Abd El-Sayed, E.S., El-Sakhawy, M., El-Sakhawy, M.A.-M. (2020), Non-wood fibers as raw material for pulp and paper industry, Nordic Pulp \& Paper Research Journal, https://doi.org/10.1515/npprj-2019-0064.

2. Bajpai, P. (2018), Nonwood Fiber Use in Pulp and Paper, In Biermann's Handbook of Pulp and Paper, Consultant Pulp \& Paper Kanpur, India, Elsevier, pp. 261-278. https://doi.org/10.1016/C2017-0-00513-X

3. European Commission (2019), Bioeconomy: the European way to use our natural resources : action plan 2018, https://op.europa.eu/en/publication-detail//publication/775a2dc7-2a8b-11e9-8d04-01aa75ed71a1 (access: 25-6-2021).

4. European Commission (2021), Pulp and paper industry, https://ec.europa.eu/growth/sectors/raw-materials/industries/forest-based/pulppaper_sk (access: 25-6-2021).

5. Fernández-Rodríguez, J., Gordobil, O., Robles, E., González-Alriols, M., Labidi, J. (2017), Lignin valorization from side-streams produced during agricultural waste pulping and total chlorine free bleaching, Journal of Cleaner Production, 142, pp. 2609 2617. https://doi.org/10.1016/j.jclepro.2016.10.198.

6. Gavrilescu, D. (2008), Energy from biomass in pulp and paper mills, Environmental Engineering and Management Journal, 7, pp. 537-546. https://doi.org/10.30638/eemj.2008.077. 
7. Gomez - Sanchez, M.D., Sánchez, R. Espinosa, E., Rosal, A., Rodríquez, A. (2017), Production of Cellulosic Pulp from Reed (Phragmites australis) to Produce Paper and Paperboard, Bioprocess Engineering, 3, pp. 65-68. https://doi.org/ 10.11648/j.be.20170103.11.

8. Gominho, J., Curt, M.D., Lourenco, A., Fernández, J., Pereira, H. (2018), Cynara cardunculus L. as a biomass and multi-purpose crop: A review of 30 years of research, Biomass Bioenergy, 109, pp. 257-275. https://doi.org/10.1016/j.biombioe.2018.01.001.

9. Hedjazi, S., Kordsachia, O., Patt, R., Latibari, A. J., Tschirner, U. (2009), Alkaline sulfite-anthraquinone (as/AQ) pulping of wheat straw and totally chlorine free (TCF) bleaching of pulps, Industrial Crops and Products, 29, pp. 27-36. https://doi.org/10.1016/j.indcrop.2008.03.013.

10. Huang, G.L., Shi, J.X., Langrish, T.A.G. (2008), Environmentally friendly bagasse pulping with $\mathrm{NH} 4 \mathrm{OH}-\mathrm{KOH}-\mathrm{AQ}$, Journal of Cleaner Production, 16, pp. 1287-1293. https://doi.org/10.1016/j.jclepro.2007.06.011.

11. Hurter, R. W. (2001), Non-wood plant fiber uses in paper making short course notes extracted from "Agricultural residues", Tappi, Ottawa Ontario Canada.

12. Kamoga, O.L.M., Kirabira, J. B., Byaruhanga, J. K., Godiyal, R.D., Anupam, K. (2016), Characterisation and evaluation of pulp and paper from selected ugandan grasses for paper industry, Cellulose Chemistry and Technology, 50, pp. 275-284.

13. Leponiemi, A. (2008), Non-wood pulping possibilities - a challenge for the chemical pulping industry, Appita Journal, 61, pp. 235-243.

14. Liu, Z., Wang, H., Hui, L. (2018), Pulping and Papermaking of Non-Wood Fibers, Pulp and Paper Processing. https://doi.org/10.5772/intechopen.79017.

15. Mutia, M., Risdianto, H. (2017), A review: non-wood plant fiber for biocomposite, Proceedings of International Workshop on Non-Wood Pulping and Papermaking Technology.

16. Naqvi, M., Dahlquist, E., Yan, J., Naqvi, S.R., Qureshi, A.S. (2018), Polygeneration system integrated with small non-wood pulp mills for substitute natural gas production, Applied Energy, 224, pp. 636-646. https://doi.org/10.1016/j.apenergy.2018.05.005.

17. Sanchez, R., Rodriguez, A., Navarro, E., Conesa, J. A., Jimenez, L. (2010), Use of hesperaloe funifera for the production of paper and extraction of lignin for synthesis and fuel gases, Biomass Bioenergy, 34, pp. 1471-1480. https://doi.org/10.1016/j.biombioe.2010.04.019.

18. Sharma, P. (2021), Opportunity of Non-Wood Forest Products in Biocomposites, IntechOpen, https://doi.org/10.5772/intechopen.97825.

19. Singh, P., Sulaiman, O., Hashim, R., Rupani, P.F., Peng, L.C. (2010), Biopulping of lignocellulosic material using diferent fungal species: A review, Reviews in Environmental Science and Bio/Technology, 9, pp. 141-151.

20. Stoica, D.E., Tofanica, B.M., Gavrilescu, D. (2010), Consideration of refining of nonwoods pulps, Celuloză şi Hârtie, 51, pp. 6-7 